\title{
The shift in World War I poetry from patriotic theme to the depiction of the dark realities of the
}

\section{War}

\author{
Ms. Twinkle Kumar
}

Department of English and Foreign Languages, Guru Ghasidas University, Bilaspur, Chhattisgarh, India

\begin{abstract}
In the beginning, war poetry was all about patriotism, indicating nobleness of war, written mostly by civilians, who had no or little experience of war. But the poetry written by the soldiers painted a totally different picture of war. This paper is concerned with a comparative study of the work of First World War poets, such as Rupert Brooke, Laurence Binyon, Wilfred Owen and Siegfried Sassoon. Brooke and Binyon's poetry was concerned with the theme of nationalism and the immortality of soldiers. But, Sassoon and Owen wrote about the horrific experience they witnessed during the war. Through their writing these poets countered and argued against all the noble ideologies related to war; instead, by expressing their true emotions, they depict war as inhumane, war weapons destructive and the lives of soldiers as uncertain.
\end{abstract}

Keywords-Patriotic, Sacrifice, Soldiers, Trenches, War poets, World War I.

\section{INTRODUCTION}

From the Anglo-Saxon times, war poetry in English was written largely by civilians, who had no experience of the actual war. So whatever they wrote was just either their own thoughts about, or imagination of, how war actually was. With the extraordinary outpouring that took place between 1914 and 1918, war poetry established itself as a genre. And although there were thousands of soldier poets, today we remember only handful of them.

The First World War started in July of 1914, and was supposed to last till Christmas of the same year; but actually went on till 1918. Consequently, young men were called from all over the world to join the army, and they gave their duty and services to their motherland. Thousands of young men enlisted in the army to play their part in the war, with only one notion in mind, namely, that participating in the war was an honourable act, and, to die for one's country was valiant. These young men, who joined the army, were completely clueless about how long it was going to last, and how much destruction it was going to cause. When the war started in 1914, writers such as Thomas Hardy, Rupert Brooke, Laurence Binyon and many others begin to encourage the people of their country through their patriotic poetry. Here, we will be comparing a few of these World War I poets and their poetry, and, try to see if, they all had same ideologies about war, or if there were some differences in their views, and if so, then how much.

\section{WAR POETS AND THEIR POETRY}

The first well known war poet is Rupert Brooke. He was one of those who joined the army willingly. Brooke's war experience consisted of one day of limited military action with the Hood Battalion. After this he wrote five sonnets, which at the time were strongly patriotic, but in the later years were derided for their hollow sentimentality. Brooke was one of those writers, who gave voice to a chivalric view of the war. In his poem Peace he put forth his views on the First World War. He begins by saying, "Now, God be thanked who has matched us with his hour, and caught our youth, and wakened us from sleeping!" The poet says that youth is not a time to be wasted. In youth, our body is full of enduring strength and so it should not be wasted in idleness and sleeping. After this the poet describes the condition of the world, which has grown old, cold and exhausted. Thus, the poet encourages the young men to leave the sick hearted people, who are unwilling to act even at this honourable hour. The poet calls these people 'half-men'. By leaving the weary world with its exhaustion, coldness, lifeless, and meaningless love, the soldier will find release in the war, where, there is no illness, grief or loss that sleep could not mend.

Similarly, in The Dead, Brooke again focuses on the positive aspects of war. In this poem, the poet considers the soldiers who have died in the war as 'Rich'. Brooke says that people who have died in the war have received a rich death. This valiant act of the soldiers to sacrifice their life for their motherland has made their worth, much more 
than gold. The soldiers have given their youth for their country. Youth is the best time of the life, a time of enjoyment and adventures. But as the soldiers are dead now, they have not only given their young age, but have also laid down their future, hopes for calm, old age, where people dream of having a family, being surrounded by their children and loved ones. But the soldier has sacrificed all these joy and pleasures of life, for their motherland. And through this great sacrifice, these soldiers have gained immortality. Their deeds have brought together holiness, love and pain, all together, that the earth was deprived of for so long. The rich dead soldiers' sacrifice has brought honour to the earth, the same honour that a king brings after a victory. And so they should be paid proper respect. Their great sacrifice is like a legacy which will be passed to the future generation. Their noble act will inspire the next generation.

Apart from Rupert Brooke, Robert Laurence Binyon, also deals with the positive aspects of the war. Laurence Binyon served as a medical orderly in the Red Cross during the World War I, because he was too old to be enlisted in the military. From 1915-1916, he worked in the military hospital in France, and his poems deal with the war as a noble cause. Shortly after the outbreak of World War I, Binyon wrote 'For the Fallen' (1914), which is a strongly patriotic poem. The poem is dedicated to the sacrifice of the thousand soldiers, who died in the battlefield. Binyon says "They shall grow not old", as we who are left behind. As the time passes it will not affect them, they will not grow old or weary. Because now they are resting peacefully in England's lap. The poet again says that the dead soldiers are like stars to their homeland, as the stars shine bright in the night, so will they shine in the time of darkness. And this is how the people of England will always remember their great sacrifice.

The common point between Rupert Brooke and Binyon is that they both have talked about the 'Great Sacrifice' of the soldiers in their poems, as mentioned above. They showed that with this sacrifice of their life, they have gained immortality. We can call this the first or early phase of World War I poetry. The second phase was inaugurated by the soldier poets themselves, who were actually out there in the battlefield, fighting in the front line and living in the trenches.

As the war continued, it caused massive destruction of both the lives of soldiers as well as the civilians, in addition to the destruction of landscape and property. This was largely due to the advancement in the science for designing deadly weapons. These weapons were not the only problem they were facing, for the soldiers had to spend most of their time in the trenches, which were filled with darkness and suffocation. They didn't even get sleep; their dreams were filled with bloodshed, horror and grief due to the loss of their soldier friends. Due to this they suffer a lot mentally, fell into depression, and were sent to military hospitals. It becomes clear that they were not only suffering physically, but mentally as well. After going through all this the soldiers begin to write about the horrific and unexpected experiences of the war. Their writings threw light on the dark, hidden realities of the war, which were totally unknown to the world before.

Wilfred Owen was one among those who tried to express the truth of the war. In 1915 Owen enlisted in the army and in 1916 he was sent to France, and within two weeks of his arrival, he was commanding a platoon on the front line. In the midst of heavy gunfire, he waded for miles through trenches, two feet deep in water, and under the constant threat of gas attacks. The brutal reality of war had a profound effect on him. When he was admitted to Craiglockhart War Hospital, he met Siegfried Sassoon, who inspired him to write. Owen died at the age of 25 , meaning at this young age he had witnessed all the horrors and terrors of the war. His poems Arms and the Boy and Anthem for Doomed Youth give us precise and detailed pictures of war. In Arms and the Boy, Owen described the deadly weapons given to young soldiers, weapons made of steel, which are keen with a thirst of blood. These weapons are hungry for flesh, to quench their thirst. The bullets which long to enter the hearts of the soldiers are sharp and accurate in giving pain and death. And there is nothing that can save these soldiers from these deadly weapons. In Dead, Rupert Brooke referred to soldiers who have died in the war as 'rich', as has been discussed above. Whereas in the opening line of Anthem for the Doomed Youth the poet compares the death of the soldier to that of cattle's', "what passing-bells for those who die as cattle?" this highlights the insignificance of the soldiers' death. The poet further says that, they are deprived of all the rituals and rites of the funeral ceremony. Because the destruction was massive no proper ritual was performed, in addition, they were buried away from their home, not by their family but by military people. Now the only homage they will be receiving is rifle fires. The poet again laments that there is no prayer or bells of the church for the funeral nor any mourning songs of the choirs. The only sound that will be heard, is the shrill and loud sound of the bugles, reminding them of home and the grief that their death will cause to the people they have left behind.

Siegfried Sassoon was another war poet similar to Owen. Motivated by patriotism, Sassoon joined the British army in 1914. His experiences on the Western front, death of his brother and his meeting with Robert Graves were the 
significant factors in his changing attitudes towards war. Dreamers by Sassoon is a significant poem, in which he has described the soldiers and called them 'Dreamers'. The poet says that, soldiers always dream about the home, that they have left behind, homes that are warm with fire, having clean beds and their wives. In the next stanza Sassoon describes the condition of the trenches, where these soldiers are living now. Mocked by reality, these soldiers hopelessly long to regain the simple pleasures of life, such as having a holiday, or picture shows, or going to office by train. They desire to go back to the normal life they once had, a life that was simple and peaceful, with their loved ones. But now, they are citizens of death's grey land. And in order to go back they must "win some flaming, fatal climax with their lives".

\section{CONCLUSION}

The difference in the writings of those who have no or little war experience to those who were actually soldiers can be easily pinned down. The former presented war as a valiant, honourable, chivalric, noble event. In their poetry as well, they presented death as a sacrifice which makes a soldier immortal. But the poetry and views of the soldiers who fought in the First World War were completely different, with their life being in danger all the time, seeing bloodshed, injuries, witnessing death of their soldier friends, experiencing the trauma of living in narrow, dark and suffocating trenches and, above all, with the prospect of being buried somewhere in the foreign land, away from home, deprived of all the funeral ceremonies, these were the new, sad and dark, but true realities of the war to them. So they took effort in writing about their experiences, and expressed the hidden truth about war. Ultimately, the so called notion of war being valiant and noble was ruined. And thus the 'War Poetry' became 'anti-war poetry'.

\section{REFERENCES}

[1] Das, Shantanu. (2014, February 7). Reframing first World War poetry. bl.uk. https://www.bl.uk/world-warone/articles/reframing-first-world-war-poetry

[2] Tearle, Oliver. (n.d). A short analysis of Laurence Binyon's 'For the Fallen'. Interestingliterature.com. https://interestingliterature.com/2015/10/a-short-analysisof-laurence-binyons-for-the-fallen/

[3] Siegfried Sassoon (1886-1967). (n.d). warpoets.org. https://www.warpoets.org/conflicts/great-war/siegfriedsassoon-1886-1967/

[4] Anthem for Doomed Youth Summary and Analysis. (n.d). Litcharts.com. https://www.litcharts.com/poetry/wilfredowen/anthem-for-doomedyouth\#: : :text=The $\% 20$ poem $\% 20$ laments $\% 20$ the $\% 20$ loss, to \%20the\%20realities\%20of\%20war3.https://www.poetryfou ndation.org/poetrymagazine/poems/13074/peace 